\title{
Implementation of Humanistic Learning Approach on Madrasah Ibtidaiyah Negeri 12 Pidie Jaya
}

\author{
Nufiar $^{1}$, Sulaiman ${ }^{2}$, Syahril $^{3}$ \\ Sekolah Tinggi Islam Al-Hilal Sigli, Sigli ${ }^{1}$, Sekolah Tinggi Agama Islam-PTIQ Banda Aceh ${ }^{2}$, \\ Serambi Mekkah University, Banda Aceh ${ }^{3}$ \\ \{kartuundangan12@yahoo.co.id ${ }^{1}$, sulaiman@ar-raniry.ac.id², syahril@serambimekkah.ac.id $\left.{ }^{3}\right\}$
}

\begin{abstract}
This research focus on humanistic learning approached on Madrasah Ibtidaiyah Negeri 12 Pidie Jaya. The research method used is qualitative with descriptive approached. Research subjects are a head of Madrasah and 10 teachers which done by purposive sampling. The data collection techniques used is the triangulation technique. Then data analized by inductive way so the research result more emphasize on meaning than generalizing. The research resulted: (1) humanistic approach implementation on Madrasah Ibtidaiyah Negeri 12 Pidie Jaya accomplished by; development management of madrasah condusively, student centered approach, development management of Madrasah condusively, and implementation cooperative learning; (2) humanistic educative interaction in learning on Madrasah Ibtidaiyah Negeri 12 Pidie Jaya, done; using interaction pattern variation in learning, sosio-emotional approached, and quality learning enhancement, and (3) obstacles in implementing humanistic learning approached in Madrasah Ibtidaiyah Negeri 12 Pidie Jaya are; limitation of tools and infrastructures especially learning class, supporting media and professionalism few teachers in teaching skill method still limited. Overall, the learning process still conducted effectively, humanist, and democratic.
\end{abstract}

Keywords: Humanistic Approach, Educative Interaction, Obstacles

\section{Introduction}

Learning is an activity process interactively facilitated by teacher to accomplish learning goal. Dede refer to Rohman's explanation that learning is an interactional process between student and his environment so that happen a change to be a better behavior (Dede. etc, 2014: 13). That process demand learning participants to be involved actively. But the reality, recently still found that learning process is not interactive and deny the learning participants as a subject of learning. This is a challenge in a learning process of humanistic approach.

Developing effort of a humanistic learning process can be conducted by a teacher involving the learning participants actively in a learning process. The teacher should be develop the learning participants optimally trough the humanistic learning process which give the learning participants opportunity to develop their potentials.

Siti refer to Johnson, one of the key success of humanistic education could be seen from their learning process. Learning used to defined as; (1) a relatively permanent change in 
response potentiality which occurs as a result of reinforced practice; (2) A change in human disposition or capability, which can be retained, and which is not simply ascribable to the process of growth (Siti Mumun Muniroh, 2011: 46). The effort to result that change can be done with humanistic approach by using cooperative learning model or learning that can activate the learning participants.

Humanistic have own vision about human. Human in humanistic vision has a soul that really potential to be developed by humanistic mechanism. Therefore according to Haryu (2006: 79), humanistic sees that psychology should be more humanis, learn about human's problems that include awareness and non awareness unsure. Humanistic really challenges inhuman treatment to human (inhumanize), include make the same of human treat to animal.

Khadijah refer to Ella Yulaelawati explain, the humanism based learning are the approach developed based on theory of humanism psychology, which emphasizing on individual development as a human (2013: 105). Humanism emphasize on human involvement in every activities as a form of potential development in the human. As well as the learning participants has potential to be developed through learning activities.

Learning participant involvement as an active subject in learning has goal sothat the learning goal achieved. According to humanistic theory, learning goal performance essence is located in the aspect of learning participant involvement in a learning process. Learning material substances will achieved and able to be absorbed by learning participants trough the learning activities done. This is the learning process that humaning human (humanize), in a writer's language "humane the participants learning trough involvement in a learning process". Khadijah refer to Hamzah that any theory can be used or implemented as long as the goal is humanizing (reach the real self actualization) achieved (Khadijah, 2013: 105).

Learning process that humanize essencely accomplished by learning method that involve the learning participants optimally in class learning process. Learning participants as an active subject in doing learning activity should be developed their potential and uniqueness by teacher trough learning model and method that relevant. Bornok (2012: 13) explain, the individual uniqueness of learning participant in teaching and learning activity should and could be seen and appreciated by educator or teacher. Effort of involvement, uniqueness development, and treatment of learning participant as an active subject should be conducted by teacher with learning method and model that relevant and challengeful.

Humanistic approach is really challengeful to a learning method that centered on teacher and considered as a learning process that admit the capability owned by learning participants. Therefore, implementation of teacher centered approach dominantly should be limited because ineffective and considered as a dehumanization process and of course inhuman.

The fact recently, the learning process in school still not humane, called not humane because in learning process, the learning participants still role as a receiver (passive) and teacher as a subject (active). The ideal is the teacher should facilitate the learning process orientated on learning participants (student centered) to create the humanist learning process. This research conducted in Madrasah Ibtidaiyah Negeri 12 Pidie Jaya, aimed to see how the implementation of humanistic learning. Researcher interested to study in that location because of based on researcher's mind, learning process in this Madrasah has been processed humanely. Beside that, there are obstacles in this implementation. 


\section{Method}

This research used qualitative research method by descriptive approach. Sugiyono (2011: 15) explained that qualitative research method is a research method based on post positivism philosophy, used to study the object condition naturally, (as an experimental opponent) where researcher is a key instrument, sample collection based on data done by purposive and snowball, collection technique with triangulation, data analyze characterize inductive/qualitative, and qualitative research result more emphasize on meaning than generalizing. Subject in this research are 10 teachers and a head of Madrasah. Then the data collection technique used is triangulation technique (composite). While data analyzed by inductively so that the research result emphasized on meaning then generalization.

\section{Discussion}

Humanistic learning approach basically rooted from the humanistic psychology ideology. From a source explain that humanistic is an ideology in psychology emerged in 1950s as a reaction to behaviorism and psychoanalysis. This ideology explicitly gives attention to human dimension from psychology and human context in development of psychological theory (http://wardalisa.staff.gu...tar+Aliran+ Humanistik.pdf).

The explanation almost the same as explained by Khadijah (2013: 105) that psychology humanism have been developing from the beginning 1950s and keep developing rapidly till recent. Humanistic in its basic theory is really challenged to a treatment that treat human inhumane. Human in humanistic perspective should be humanize, respect each other, and democratic. Thus in learning process, learning participants seen as an active subject that should be humanize and democratize.

Humanistic known with learning theory that emphasized on involvement aspect of learning participants in learning process and give attention on aspect of personal development of learning participants. This is in line with the explanation of M. Thobroni (2016: 133) that humanism sees more to human personality development side. This approach sees the situation, how human develop his self to conduct positive things. This ability to conduct positive called human potential and educators who have humanism ideology usually focus the learning on developing this positive capabilities. Positive capabilities have a strong relationship with positive emotional development which in affective domain. Emotion is a really strong characteristic seen from educators with humanism ideology. Next, Sitti (2008: 6) in her research describe that in learning process are the learning participants have need of study, understand learning techniques, and behave of learning.

That explanation signed that learning is an effort to help teach participants to develop their capabilities through the learning-teaching process facilitated by teacher in class. Ida Bagus (2013: 96) explain that the main goal of educators is helping student to develop his self, which help each individual to know their self as a unique human and help to create potentials inside them. That's the task obliged by teacher in learning process in humanistic view. Further explanation related to research result will be discussed on following description. 


\subsection{Implementation of Humanistic Learning Approach in Madrasah Ibtidaiyah Negeri 12 Pidie Jaya}

Implementation of humanistic learning philosophically relate on effort in developing learning process to humane human (humanize). Uci Sanusi refer to explanation of Paulo Freire that learning in humanistic approach, perceivable as a learning that directing to process of humane a human (2013: 123). Further Uci Sanusi (2013: 123) cites from Burhanuddin and Moh. Makin in Endi Supriadi clarify that education which humanize is a process of guiding, developing and directing basic potency of a human, physically and spiritually in a harmony with respect to other humanistic norm. So that the learning process in human perspective is effort to guide and develop basic potential of learning participants with considering their uniqueness trough learning strategic that involve learning participants' involvement actively.

Effort to develop humanist learning in education unit, include in Madrasah should be supported by the humanist system in Madrasah; a humanist madrasah management, teacher, madrasah culture, and a conducive environment; therefore a humanist learning atmosphere developed.

Learning according to humanistic theory aimed to humanize. Learning participant's trough process learning directed to become capable in self actualization. One of teacher explain that implementation of humanistic education in learning process of Hadits subject aimed to involve the learning participants in hadits learning process actively, this is the part of humanist learning. The same explanation also described by a math teacher that humanistic learning approach aimed to create learning process that humanize, which mean the learning participants involved in learning process wholly. The same explanation also described by other teachers, generally that humanistic learning approach in learning aimed to optimizing learning role of learning participants. Implementation of humanistic learning in Madrasah Ibtidaiyah Negeri 12 Pidie Jaya trough four aspects:

\section{a) A Condusive Madrasah Management}

Effort to develop an effective madrasah management to support creation of humanistic learning process conducted by head of Madrasah Ibtidaiyah Negeri 12 Pidie Jaya, with the next five steps:

1. Involve all unsure in management system of madrasah

2. Optimizing teacher role in madrasah management to develop a humanist madrasah management.

3. Optimizing administration staff in a madrasah management system.

4. Head of madrasah use democratic leadership approach in a madrasah management system.

5. Create a condusive madrasah environment.

\section{b) Approach of Student Centered Learning}

Based on some information attained in field that strategy accomplished by teaching teacher in Madrasah Ibtidaiyah Negeri 12 Pidie Jaya to create humanist learning process conducted by using student centered learning approach (learning approached oriented to learning participants). Using student centered learning aimed to involve learning participants actively in a learning process. Trough this approach, learning participants can optimize their capacity of learning and interact with peer to peer, also the learning participants discussable, argue with their learning experiences. Beside, this implementation of student centered learning approach 
implied positively to learning activeness of learning participants' so that will sharpening their critical personality.

\section{c) A Conducive Learning Situation}

Situation of concussively learning is an important element to support humanistic learning process. That's why teacher in Madrasah Ibtidaiyah Negeri 12 Pidie Jaya confirmed to get developed this conducive learning situation with structuring and ordering the relevant procedure to build a conducive class. Tree strategies following conducted by teacher of Madrasah Ibtidaiyah Negeri 12 Pidie Jaya to create a humanist learning situation:

1. Class rule approach, teacher explains about appropriate behavior conducted by learning participants in class while learning process going on.

2. Explain to learning participants about the appropriate behavior in learning.

3. Preventive, about what should be done to avoid behavior that can destruct the learning situation.

Those strategies also implied in developing a conducive and humanist learning situation. This is in line with Sulaiman's explanation "The humanistic classroom situations can be built by creating an enabling environment, both physical and nonphysical" (Sulaiman, 2017: 156). Therefore, effort to create a humanist learning situation can be supported by a conducive class situation.

\section{d) Cooperative Learning}

Cooperative learning has advantages to involvement of active participation of learning participants in a learning process. One of teacher explain that implementation of cooperative learning in Fikih learning useful to encourage activity of learning participants during learning process. The next teacher explain that basically a lot of learning model that can be used to develop quality and involvement of learning participants while learning process, in example a teacher can use cooperative learning. This is also supported by head of school's explanation that used of cooperative learning model in learning math, learning participant looks actively while doing learning activity and interdependently working together.

Based on those information can be concluded that used of cooperative learning model in Madrasah Ibtidayah Negeri 12 aimed to create a humanist learning process, learning process that involve learning participants role optimally. This is the form of humanize process. Further five positive implication of cooperative learning implementation to develop humanistic learning process in Madrasah Ibtidaiyah Negeri 12, which are:

1. Usage of cooperative learning model to involve active role of learning participants.

2. Usage of cooperative learning model to optimize learning participants' role during learning process.

3. Develop a fun learning.

4. Develop learning motivation inside learning participants' self.

5. Create a conducive learning situation.

\subsection{Humanistic Educative Interaction During Learning In Madrasah Ibtidaiyah Negeri 12 Pidie Jaya}

Learning mentioned as an interactive and active process that done with two components, which are teacher and learning participant. Educational interactive in the process involve two 
stakeholders, a teacher and learning participants actively in conducting teaching and learning activity. Nuni said (2013: 121) that educative interaction should described two ways with a number of knowledge as its media, so the interaction is a meaningful and creative connection. All educative interactional unsure should processed in educational purpose bonding. Therefore, educative interaction is a picture of two ways active relationship between teachers and learning participants that going on inside the bond of education purpose.

Learning is an active interactional process, two ways, teacher and learning participants, contained norm and purpose of learning, as a goal that will be achieved. This almost in line with Djamarah explanation that learning teaching is an interaction that has a normative value. Djamarah (2010: 12) continue that learning teaching is a process that conducted by awareness and purposive. The purpose is as guidance to which way the learning teaching process will direct to. Learning process will succeed if the result is able to create change in knowledge, comprehension, know how, and value-attitude inside learning participant's self.

Educative interaction basically is learning interaction or learning process during and referring to normative value and specific purpose. Normative value could be comprehended that learning process by referring to value or advantage usage that will be resulted from learning-teaching interaction. Humanistic education interaction in this could be comprehended by an interaction or during learning process by referring to a fundament of optimizing learning participants in learning process optimally. Learning participants facilitated to conduct process of learning effectively trough learning approach and pattern that give learning opportunity for learning participants.

According to strategies that teacher conducted in Madrasah Ibtidaiyah Negeri 12 Pidie Jaya that creating humanistic educative interaction, further detail described based on information founded in study of field:

\section{a) Interaction Pattern During Learning Process}

Learning process ideally can be conducted humanly, which is the learning process humanize. Humanistic learning process basically is a learning process that emphasized on learning participants involvement. Practice of humanistic learning facilitated by a teacher using student centered learning approach and interaction learning pattern. This is the part of humanist learning process. Sulaiman (2017: 107) explained that reformation of learning process demand change on learning interaction aspect which no longer happening in one way, from educator to learning participants, but the learning interaction process happen with many ways.

Interaction pattern in humanistic learning process can be conducted with variety pattern or many pattern. This is in line as explanation of one teacher that developing strategy and creating learning process that humanist can be conducted by a teacher with many patterns, but the most important thing is the teacher comprehends that patterns. Close resemblance explanation given by other teacher that effort of developing humanistic learning process or humanist learning can be conducted with using many direction learning patterns, with many direction learning patterns will be created interaction that effective so that learning participants will actively doing their learning activity. Close resemblance explanation also done by other teacher that there is important aspect should be noticed by a teacher during the learning process, which is active role of learning participants, this aspect should be prominent attention during learning process, because without attention to role of learning participants during learning process which mean that dehumanization been happen during learning process, which 
is suppression to the learning right of learning participants. And these things should not be happened.

Based on various information attained that strategy to create interaction of humanistic learning in Madrasah Ibtidaiyah Negeri 12 Pidie Jaya conducted by three interactional patterns, following:

1. Many ways interactional patterns (teacher-learning participants-teacher-learning participants-learning participants)

2. Two ways interactional pattern (teacher-learning participant-teacher)

3. One way interactional pattern (teacher-learning participants)

Using interactional pattern aimed to involve learning participants actively during learning process and also worthwhile for building social-emotional during learning process. Further, that interactional learning useful, of course should be based on consideration of optimizing learning process, not all of those pattern right to use in all learning situation.

Effort to develop humanist interactional pattern during learning process can be conducted by using variety patterns of learning and implied to acceleration of learning interest from learning participants. This is as Sulaiman's explanation, pattern variety of those learning teaching interaction implied positively to accelerate student's learning interest and can avoid learning boring (Sulaiman, 2015: 96-97).

Ahmad Ta'rifin (2009: 104) added that humanistic interactional which are new a concept of relationship pattern of teacher student in learning process that put forward democratic attitude and teacher's transparency; student's activeness, independency and innovative; teacher's hospitality and student's well mannered; mutual respect eliminate teacher's tend to become authoritarian as a feudalistic bureaucracy legacy, closure attitude and arrogancy of a teacher.

Learning process that not involve learning participants' activeness in humanistic view is part of tricking process of learning participants or called by dehumanize. Learning process like this are challenged by humanistic theory follower. It is like Ahamd Ta'rifin's explanation just as same as Freire, Ivan Illich also assume that dehumanistic interaction has shackle learning participants, because teacher over role: as a monitored, moralist, and therapist, so that limit learning participant's movement and alienate them from social environment (Ahmad Ta'rifin, 2009: 106). Therefore, learning interactional process should be addressed and applied wisely to involve learning participants and create a humanist learning process.

\section{b) Socio-Emotional in Humanistic Learning}

Learning process will be processing effectively and humanist if supported by an effective socio-emotional. Socio-emotional relationship between teacher and learning participant should be in good relationship, sot hat will emerge a harmony learning situation in class. Ahmad Rohani (2010: 173) explain that there are two assumption relate to socio-emotional approach in learning, which are: (1) an effective learning teaching process required a good socioemotional climate which mean there are a good interpersonal relationship between teacherlearning participants and inter learning participants, and (2) teacher occupied most important position to form that good socio-emotional climate.

An effective interpersonal relationship should be developed well during learning process to create a humanistic learning process. Learning process go on in a conducive learning situation, interactional relationship between teacher and learning participant-learning participant with other learning participant intertwined well in class to support conducting of a humanist learning process. Effort to create and develop a good socio-emotional relationship in learning 
process in Madrasah Ibtidaiyah Negeri 12 Pidie Jaya conducted by teacher using three following approach:

1. Individual approach, use to know learning participant's personality so that teacher can help learning participants in conducting his/her learning process, beside that also created a harmonic relationship between teacher and learning participants.

2. Group approach, done by way to approach learning groups and give learning guidance assistance. Trough this approach the learning participants also able to explain their hardness while conducting their learning activities. Beside that, this approach also implied positively to a good interpersonal relationship between teacher and learning participants during learning process.

3. A thorough approach, teacher should give attention thoroughly during learning process in class so that learning participants get the same attention while learning process on going.

\section{c) Learning Quality Enhancement}

Qualitative of learning process can be seen from the height of active role of learning participants and their involvement in learning process. Information attained from teacher that effort to enhance quality of learning can be done by using learning media, interactive learning and discussion method. This method usage can stimulate learning participants learn actively. Following described the strategy of learning quality enhancement in Madrasah Ibtidaiyah Negeri 12 Pidie Jaya to create a humanistic learning process done by teacher with four aspects, which are:

1. Usage of discussion method (interactive), aimed to enhance learning role of learning participants.

2. Usage of variation teaching method, aimed to stimulate learning of learning participants and avoid learning boring.

3. Usage of learning media, aimed to enhance learning quality and motivate learning participants to learn, media available in madrasah are laptop.

4. Creation of a conducive learning climate, aimed to develop learning spirit.

Teaching skill of a teacher implied on creation of interactional process of humanistic learning. Teacher should be completed with a great of experiences in managing students learning activity.

\subsection{Obstacles in Implementing Humanistic Learning Approach in Madrasah Ibtidaiyah Negeri 12 Pidie Jaya}

Obstacles in developing a humanist learning process, wether in school or madrasah still have obstacles to face. Neni refer to Kamil's explanation that learning obstacle usually emerge from learning citizen or from learning source, or from a non adequate structure and infrastructure (Neni Ana Nofita, 2013: 154). Development of humanistic learning is supported ideally by many learning unsure. What include in supporting unsure of humanistic learning process are a condusive management madrasah; a professional teacher; role optimization of learning participants; supporting learning structure, et cetera.

Implementation of humanistic learning approach in Madrasah Ibtidaiyah Negeri 12 Pidie Jaya is not effective yet, mentioned that because of in its implementation still inadequate of supporting structure sothat impact negatively to unefectiveness of learning process. Following described three obstacles in implementing humanistic learning on Madrasah Ibtidaiyah Negeri 12 Pidie Jaya, which are: 
a. Madrasah structure. Madrasah Ibtidaiyah Negeri 12 Pidie Jaya recently is one of in demand of Madrasah Ibtidaiyah by community around. A great of enthusiasts factor impacted to inadequate of structure like class room as a main structure in learning process. However, head of madrasah and teacher really optimist in conducting task to educate nation generation, although in class room inadequate situation.

b. Beside class room, media limitation of availability media is an obstacle factor for developing a humanist learning on Madrasah Ibtidaiyah Negeri 12 Pidie Jaya.

c. Teacher skill in creating humanistic learning process. Teaching skill of a teacher is another obstacle in developing a humanist learning process on Madrasah Ibtidaiyah Negeri 12 Pidie Jaya. Recently still some teachers teach monotonely, teacher still use teacher centered approach sothat learning participants becoming more passive. It is like observation result in field that still founded teachers teach just focus on using one method, which is lecturing method. Therefore, teaching skill is really important in creating a humanist learning process.

\section{Conclusion}

Implementation of humanistic learning approach on Madrasah Ibtidaiyah Negeri 12 Pidie Jaya, trough; (1) madrasah management condusively with involving all madrasah citizen participate in creating a condusive, humanist and democratic learning process, (2) student centered learning approach (learning oriented to learning participants) aimed to facilitate learning activity and develop learning participants potential, (3) development a condusive learning situation done by using class management approach, and (4) implementation of cooperative learning to involve participants actively in learning process.

Humanistic educative interactional strategy of learning on Madrasah Ibtidaiyah Negeri 12 Pidie Jaya, done by (1) using pattern variation of interactional in learning; many ways interactional pattern (teacher-learning participant-learning participant-teacher-learning participant-learning participant), two ways interactional patters (teacher-learning participantteacher), and one way interactional pattern (teacher-learning participant), (2) socio-emotional approach, and (3) enhancement of learning quality.

Obstacle in implementing humanistic learning approach on Madrasah Ibtidaiyah Negeri 12 Pidie Jaya, are; (1) class room limitation because of a great amount of enthusiastic learning participants factor to learn in this madrasah, (2) media limitation available in this madrasah, and (3) teaching skill some teachers in developing humanistic learning process still inadequate.

\section{References}

[1] Ahmad Rohani (2010). Pengelolaan Pengajaran (Sebuah Pengantar Menjadi Guru Profesional). Cet. I. Jakarta: Rineka Cipta.

[2] Ahmad Ta'rifin. Membangun Interaksi Humanistik dalam Proses Pembelajaran. FORUM TARBIYAH Vol. 7, Num. 1, June (2009).

[3] Bornok Sinaga, Pendidikan Dan Pembelajaran Yang Demokratis Dan Humanistis (Refleksi terhadap Paradigma, Proses, dan Produk Pendidikan Sebagai Dasar Revitalisasi Prinsip dan Nilai Pendidikan di Indonesia), Generasi Kampus Magazine/Journal. Vol. 5. Num. 2, September (2012). 
[4] Dede Irawan Saputra. Dkk, Pengembangan Model Evaluasi Pembelajaran Project Based Learning Berbasis Logika Fuzzy, INVOTEC, Volume X, Num.1, February (2014).

[5] Haryu. Aplikasi Psikologi Humanistik dalam Dunia Pendidikan di Indonesia (konsep Arthur W. Combs tentang Pengembangan Potensi Anak). Tadrîs Volume 1. Number 1. (2006).

[6] Ida Bagus Putrayasa (2013). Landasan Pembelajaran. Bali: Undiskha Press.

[7] Khadijah (2013). Belajar Dan Pembelajaran. Cet. I. Bandung: Citapustaka Media.

[8] M. Thobroni (2016). Belajar\&Pembelajaran Teori Dan Praktik. Cet. II. Yogyakarta: Ar-Ruzz Media.

[9] Neni Ana Nofita. Hambatan-Hambatan Warga Belajar dalam Proses Pembelajaran Program Paket C di Kecamatan Pancung Soal Kabupaten Pesisir Selatan. SPEKTRUM PLS. Vol. I, Num.1, April 2013.

[10] Nuni Yusvavera Syatra (2013). Desain Relasi Efektif Guru Dan Murid. Cet. I. Jogjakarta: Buku Biru.

[11] Pengantar Aliran Humanistik. http://wardalisa.staff.gu...tar+Aliran+ Humanistik.pdf. (Online). Dated on January 2, (2017).

[12] Siti Mumun Muniroh, Aliran Psikologi Humanistis Dalam Proses Pembelajaran, Forum Tarbiyah Vol, 9. Num. 1, June (2011).

[13] Sitti Roskina Mas. Profesionalitas Guru Dalam Peningkatan Kualitas Pembelajaran. INOVASI, Volume 5, Number 2, June (2008).

[14] Sugiyono (2011). Metode Penelitian Pendidikan Pendekatan Kuantitatif, Kualitatif, dan R\&D, Cet. XIII. Bandung: Alfabeta.

[15] Sulaiman. Menjadi Guru PAI Yang Dirindukan Peserta Didik Dalam Kelas. Proceedings seminar 1st Annual International seminar on education 2015 Faculty of Tarbiyah and Teacher's Training State Islamic University of Ar-Raniry Banda Aceh, (2015).

[16] Sulaiman (2017). Metodologi Pembelajaran Pendidikan Agama Islam (PAI) (Kajian Teori Dan Aplikasi Pembelajaran PAI). Printed. I. Banda Aceh: Yayasan PeNa.

[17] Sulaiman.The Implementation Of Humanistic Learning At Darul Aman Islamic High School In Aceh Besar. Jurnal Ulumuna, Vol. 21, No. 1 June, (2017).

[18] Syaiful Bahri Djamarah (2010). Guru\&Anak Didik dalam Interaksi Edukatif, Ed. Rev. Cet. III. Jakarta: Rineka Cipta.

[19] Uci Sanusi. Pembelajaran Dengan Pendekatan Humanistik (Penelitian Pada MTS Negeri Model Cigugr Kuningan). Jurnal Pendidikan Islam Ta'lim. Vol. 11. Num. 2 (3013). 